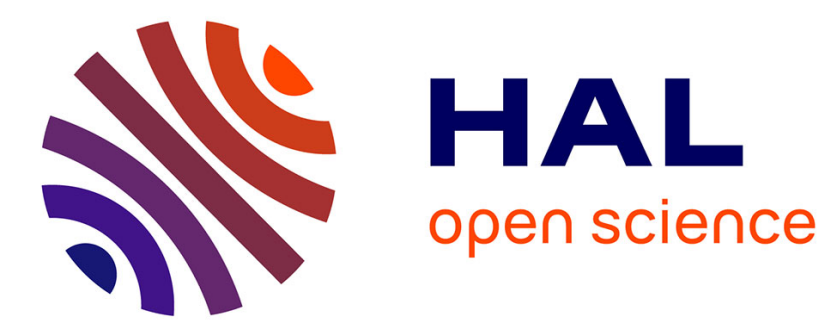

\title{
The economic and social consequences of the arms race Jacques Fontanel
}

\section{To cite this version:}

Jacques Fontanel. The economic and social consequences of the arms race. Swedish Initiative against nuclear weapons tests, University of Stockholm, Nov 1990, Stockholm, Sweden. hal-03292656

\section{HAL Id: hal-03292656 \\ https://hal.univ-grenoble-alpes.fr/hal-03292656}

Submitted on 20 Jul 2021

HAL is a multi-disciplinary open access archive for the deposit and dissemination of scientific research documents, whether they are published or not. The documents may come from teaching and research institutions in France or abroad, or from public or private research centers.
L'archive ouverte pluridisciplinaire HAL, est destinée au dépôt et à la diffusion de documents scientifiques de niveau recherche, publiés ou non, émanant des établissements d'enseignement et de recherche français ou étrangers, des laboratoires publics ou privés. 


\title{
The economic and social consequences of the arms race Jacques Fontanel
}

\author{
Expert "Swedish Initiative against nuclear weapons tests", \\ University of Stockholm, \\ Novembre 1990
}

\begin{abstract}
Résumé: Les efforts de l'ONU en faveur du désarmement pour le développement sont importants dans le cadre d'une économie mondiale aux fortes disparités sociales et concernée par une course aux armements entre les grandes puissances. Cette situation est humainement difficile à accepter compte tenu du potentiel de richesses dans le monde entier et de la précarité des situations de paix. Deux questions fondamentales interpellent l'économiste concernant la militarisation du monde. Les dépenses militaires mondiales participent-elles activement au sous-développement des pays du tiers monde? Un processus de désarmement est-il susceptible de favoriser le développement économiques et si oui dans quelles conditions? Il faut ajouter que tout processus de désarmement ne peut s'engager que si les forces en présence sont toujours en mesure de s'annihiler par un équilibre des forces fondé non pas sur la comparaison des dépenses militaires, mais sur l'état réel des forces militaires en présence.
\end{abstract}

The UN's efforts to promote disarmament for development are important in the context of a global economy with strong social disparities and an arms race between the major powers. This situation is humanly difficult to accept, given the potential for wealth throughout the world and the precariousness of peace situations. Two fundamental questions challenge the economist regarding the militarisation of the world. Is global military expenditure actively contributing to the underdevelopment of third world countries? Is a disarmament process likely to promote economic development and if so, under what conditions? It should be added that any disarmament process could only be undertaken if the forces involved are still able to annihilate each other through a balance of power based not on the comparison of military expenditure, but on the actual state of the military forces involved.

Mots clés : Tiers-Monde, Désarmement, Développement économique, Sécurité internationale, FIDD.

Third World, Disarmament, Economic Development, International security, IDFD 
Disarmament for development is an ancient idea, rooted in human history. Weapons are considered burdens, but each state wishes to protect itself from predation, from the invasion of its territory or from the exercise of domination by one or more other states. Under these conditions, it is necessary to engage in disarmament that does not call into question international balances. For development aid to be strengthened by the process of disarmament for development, political (based on trust and negotiation), technical (transparency of information, verification of military expenditure) and institutional (should an ad hoc organisation be created or not?) conditions must be met.

Economic development conflicts are as deadly as military ones. The defence of a country cannot be reduced to the military sphere alone. One may wonder whether the expenditure devoted to the military sector is not partially incompressible, due to a strong substitution between police and defence expenditure, both of which serve globally to manage and settle relations between people and between communities.

Basically, there are three fundamental questions for the economist concerning the militarisation of the world.

1) Is global military expenditure actively contributing to the underdevelopment of Third World countries?

2) Does military spending lead to better international security or not?

3) Is a disarmament process likely to promote economic development and if so under what conditions?

Historically, military expenditure has been an important factor in underdevelopment, facilitating the establishment of colonialism or slavery. Predation and the struggle for power and might are scourges that, unfortunately, have always existed. The third world is an economic and military issue, which has been concretely expressed through colonisation and military conflicts. Colonisation is often seen as the main reason for underdevelopment, as it led to the expansion of export crops at the expense of food crops, mining, the degradation of terms of trade, the construction of specialised communication routes directed towards the metropolis, the destruction of local crafts by competition from manufactured goods and the establishment of aberrant national borders.

The domination of the great powers was expressed through intervention in territorial spheres of influence and the 
warlike expression of ideological conflicts. In addition, civil conflicts, inter-state wars and the emergence of regional powers have emerged as powerful brakes on the economic development of the poorest countries.

Even in the absence of armed conflict, military expenditure does not seem to have a positive effect on development. Thus, Benoit's famous study, according to which the military effort would promote industrial modernisation, the training and information of men, the improvement of infrastructures and the full use of the production capacities of the economies of the South, and would not constitute an obstacle to their development, has been strongly contested both in form and in substance. The impact of military expenditure on growth depends on the effective use of the productive capacities of national economies. In terms of opportunity costs, civilian investments are a priori more favourable to economic development. Moreover, there is a fairly general substitution relationship between investment and military expenditure, which can however be overturned in case of collective acceptance of the financial effort of defence. Most econometric studies point to the negative effects of military spending on short-term economic growth in developing countries.

Arms production is often conceived as a national security imperative. States can maintain military production, even if it is not financially viable in peacetime. However, without a good national research and development system, the security of countries is constantly under threat, unless covered by a military alliance. Technological competition is never-ending and accelerates obsolescence.

This makes it difficult for developing countries to claim economic and military independence, as they have to obtain foreign licences, which are often technologically out-dated, for equipment essential to their defence. Under these conditions, national production can be counterproductive to national security. From an economic point of view, contrary to what has often been argued, defence industries hardly save scarce resources and they do not have the desired industrialising effects.

The arms industry does not really promote economic growth, let alone industrial integration, because empirically the multiplier effects are relatively small. Military technologies are "baroque", highly developed, but not very profitable. Moreover, 
military activities, because of defence secrecy and the disarticulation of the least developed economies, do not have the possibility of infusing the national economy of the poorest countries with complementary activities, especially concerning the intermediate consumption of the arms industries. The disadvantages of national arms production on the economic development of Third World countries are very important, in particular the economic dependence on the export of arms necessary to obtain economies of scale, the contemporary maladjustment of military technology to civilian technology and the importance of the opportunity costs of using highly qualified personnel in the military sector to the detriment of the civilian sector.

The world's states are in economic and military competition, lending credence to the idea of a continuing conflict, from the threat of nuclear war, through local wars or economic retaliation. The economy itself often appears as a weapon, through the exercise of embargoes, protectionism or the economic potential devoted to the power of the nation. It is difficult to create the conditions for national security without a strong economy, both to make the armament effort acceptable to the population and to equip itself with adequate military or civilian vectors to resolve a possible conflict in its favour. Under these conditions, developing countries are at a great disadvantage because of their low production and defence capacity.

A reduction in military expenditure or disarmament not only has the potential to improve the macroeconomic results of the countries concerned, it also modifies the distribution of the benefits of growth, partially redistributes the cards of international competitiveness and thus transforms certain fragile balances with the sometimes unbearable tensions that are implied by periods of transition. Under these conditions, disarmament for development, however useful it may be in itself for the whole of humanity, must be undertaken with caution.

In 1989 , more than $\$ 1,000$ billion in military expenditure is projected. These estimates are very rough, as the actual military expenditures of states are not well known. Military secrecy, heterogeneous definitions and the technical difficulties of international comparisons limit the quality and use of available information. The military effort absorbs $6 \%$ of the wealth produced annually in the world, but nuclear expenditure 
does not exceed $12 \%$ of this global military expenditure, i.e. $0.7 \%$ of global GDP.

Thus, a reduction in military expenditure of the order of $10 \%$ is only applicable if it concerns several types of weaponry. More than 50 million people are directly employed in the military effort and 40 million people are employed in activities closely related to the needs of national defence. More than 500,000 top scientists work primarily for the military sector and global research and development, heavily dominated by the US, the USSR, West Germany, France, the UK, China and Japan, is financed for more than a quarter of the money spent by the military sector.

The idea that military expenditure is an inadmissible diversion of resources available for the good of humanity is enshrined in the UN Charter. However, it is not necessarily unnecessary if it is capable of deterring at an optimal (not maximum) level adversaries bent on wealth predation and violence for power. While military expenditure is analysed as an important factor in international relations, it is also a producer of domination effects and imperialist temptations.

According to Marxist theory, the growth of military expenditure is a necessity of the market economy system, in order to fight the internal contradictions inherent in the capitalist mode of production.

In a famous study unveiled by Galbraith, the question of the utility of wars was asked and it was concluded that the functions of armed conflict promoted the stability of the national economy and the power of the US. The military effort, by sterilising part of the economic surplus and improving national unity, was a necessary condition for US power and economic development. Substitutes for war do not really exist. Organised waste is necessary to sustain the American political system.

Finally, the idea that conflicts are also expressed with economic weapons reinforces the heterogeneity of the economic analysis of military expenditure and makes it even more questionable. Basically, disarmament without eradicating the causes of the arms race is probably doomed to failure, unless one limits one's ambition to the very delicate concept of reducing military expenditure or eliminating over-armament.

Military expenditure satisfies the need for security of a national community against external threats. The role of military expenditure is therefore contradictory: if it prevents conflicts by 
deterring external aggression, it contributes directly to the improvement of the well-being of populations (in the same way as police and justice expenditure for internal security), but it is also a factor and a vector of war; in this context, it is antieconomic in that it destroys without compensation. However, increased military spending by two enemy states often leads to the mere maintenance of international security. Under these conditions, a negotiated reduction of military expenditure between the two countries could be considered, since the additional security needs of both countries are not met. This is the context in which a disarmament-for-development negotiation can take place, since reductions in military spending are likely to improve the economic development of both countries and of the developing countries that will receive the aid associated with the programme, given equal security.

There are four basic obstacles to reducing military spending: distrust and lack of political will on the part of states, the imperfect representativeness of military spending as an indicator of the forces at work, the secrecy of statistical and budgetary information about the defence sector in all countries (with varying degrees of intensity), and the danger of reducing military spending without seeking to limit the causes of the arms race. However, negotiated disarmament without extension to the economic and social sphere would have a very uncertain future, since it could lead to new inequalities and the emergence of tensions typical of periods of change, thus creating the conditions for progressive rearmament.

For Leontief and Duchin, disarmament for development is an effective procedure. In their global econometric model, they show that a disarmament measure would have a positive effect on all regions of the world and that resource transfers would significantly increase consumption and GDP per capita in arid African countries, low-income Asian countries and tropical Africa; although these results are spectacular for poor, sparsely populated countries, they have little econometric significance.

Other econometric studies converge on the same conclusions. While it is true that in the long run disarmament is a positive factor for the economic development of all nations, in the short run it raises important macroeconomic and sectorial conversion difficulties. For developing countries that do not have arms industries, the effects of reduced military spending are positive, as it promotes more efficient use of scarce resources. 
For arms-producing countries, a disarmament process can have adverse effects in the short term, especially for industries and regions directly or indirectly affected by arms activities. In the long term, the effects should be positive, if the economic downturn caused by the reduction of internal arms purchases does not lead to irreversible recessionary effects, especially in terms of business conversion.

The idea of creating an International Disarmament Fund for Development (IDFD) is not new and has been the subject of numerous proposals and studies that have failed politically. The creation of an IDF would be symbolic, however, as it would express the refusal of states to voluntarily use the military sector for national economic development based on the power of arms and the direct or indirect effects of military domination. While disarmament should have positive effects on economic development, it is also necessary to maintain the balance in international security. The transfer of resources from rich to poor countries seems, a priori, an interesting measure to reduce development inequalities and state antagonisms. However, there are pitfalls to be avoided, both for developed and developing countries and in the relationship between disarmament and development.

For developed countries, military contracts and arms industries create vested interests that are politically and economically difficult to challenge. Disarmament may lead, in the short term, to increased underemployment, painful industrial and territorial restructuring, and reductions in income and wages. Changing a tank manufacturing company into an allterrain truck company is certainly technologically possible, but there will then be the critical problem of product cost and the existence of an adequate market. Just because you can turn military aircraft production into civilian aircraft does not mean that you can simultaneously develop an already crowded market. Furthermore, it is unlikely that the governments of the major powers will accept that the distribution of wealth is too unfair and that the developed countries must give up part of their wealth for the well-being of the poorest countries. This would be a major political act.

Developing countries must avoid the transfer being pauperising in total. A transfer received may not be conducive to economic development if a particular social group that decides to allocate it to jobs that are unproductive for the country (capital 
exports, imported luxury goods, demonstration effects, etc.) confiscated. In other words, a transfer is only of economic interest to a country if it is embodied in highly productive activities. Furthermore, a transfer of resources can be an opportunity for new markets for developed countries and a new dependency for developing countries. If the transfer is in inconvertible currency, the receiving country must necessarily purchase from the donor country, which may take advantage of this to reintroduce unequal trade flows. If the transfer is made in kind, it is not obvious that the product concerned will satisfy the development needs of the recipient countries; for example, if the aid is given in the form of a commodity that competes directly or indirectly with national industry, the result may in the long run be very negative for the Third World, especially as each product and service carries with it a culture and the dominant values of the society for which it was created.

While economic factors are important in the concept of disarmament for development, strategic and political constraints appear to be decisive. Indeed, the level of military expenditure is a very imperfect indicator of a country's power. The same expenditure leads to very different security situations depending on the geographical location of states, international arms control agreements or the different 'bang for a buck' depending on the type of weapons chosen. For example, a 10\% reduction in military expenditure between two countries with equivalent expenditure does not necessarily lead to a homothetic reduction in forces, particularly with regard to the holders of nuclear weapons. This is why a financial agreement on the reduction of military expenditure also implies a strategic reflection on the comparative evolution of forces. At the political level, the idea of disarmament for development must not be simply a negotiating tool without operational significance. The political will of the major powers to reduce their military potential is crucial.

While the Brandt, Palme and Thorsson reports condemn the use of public funds in the military sector to the detriment of public health and education, econometric studies verifying the negative relationship between health and military spending provide contradictory results. For developing countries, the least militarised countries also spend proportionally the least on health and education. Moreover, there is little impact on civilian public infrastructure as a result of financial efforts to reduce military spending. 
The relationship between military spending and developing countries is more complex than a cursory analysis might assume. One should be wary of the obvious. While at the global level there is no doubt that developing countries bear the burden of their armaments, the removal of these can have irreversible military and economic effects, undoubtedly worsening their poverty situation if their vulnerability limits their resistance to the eternal predation of the strongest. It is wrong to say that any process of disarmament leads to an improvement in collective well-being; it can even be the occasion for a generalised regression if it is accompanied by political, military and economic domination of another country or by an unsustainable development of social inequalities.

It would demonstrate the willingness of states to provide solutions to three of the great scourges that threaten the world, namely the recurring economic crises that foster the growth of international and social inequalities, and the arms race in an age when nuclear and bacteriological weapons (although banned, can still be built secretly) are physically capable of destroying life on Earth. The issue of the environment and ecology is likely, in the coming years, to become an important subject of conflict between states and people with divergent interests in the future of humanity (Fontanel, 1979).

Bibliography

Benoit, E. (1978), Defence and economic growth in developing countries, Economic Development and Cultural Change, 26.

Brandt, W. and al. (1980), North-South, a programme for survival, Independent Commission on International Development Issues.

Cars, H.C., Fontanel, J., (1985), Military Expenditure Comparisons, in Peace, Defence and Economic Analysis, Mac Millan, London, 1987.

Colard, D., Fontanel, J., Guilhaudis, J-F. (1981), Le désarmement pour le développement, Vol 19, Fondation pour les Etudes de Défense Nationale.

Deger, S., Smith, R. (1986), Military expenditures in third world: the economic effects. Routledge \& Keegan.

Fontanel, J. (1979), Ecologie, Economie et Plurigestion, Edition Entente, Paris.

Fontanel, J. (1982), Military Expenditures and Economic Growth (France, Morocco), Report for United Nations.

Fontanel, J. (1984), L'économie des armes, La Découverte, Paris. 
Fontanel, J., Smith, R. (1985), L'effort économique de défense, Ares, Défense et Sécurité, Supplément $\mathrm{n}^{\circ} 4$

Fontanel, J., Smith, R. (1985), Analyse économique des dépenses militaires, Stratégique.

Fontanel, J. (1985) Introduction à l'effort économique de défense, Arès, Défense et sécurité.

Fontanel, J. (1985), L'effort économique de défense, Arès, Défense et sécurité.

Fontanel, J., Saraiva-Drummond, J. (1986), L'industrie d'armement comme vecteur du développement économique, Etudes Polémologiques, $\mathrm{n}^{\circ} 40$,

Fontanel, J. (1987), A note on the International Comparison of Military Expenditures, The economics of military expenditures. Palgrave MacMillan,

Fontanel, J. Smith, R. (1987), The creation of an International Disarmament Fund for Development, Defence, Security and Development, Frances Pinter,

Fontanel, J. (1989) L'armement et la santé dans les pays du TiersMonde, International Physicians for the Prevention of Nuclear War, Montréal, 1988,

Fontanel, J. (1989), Désarmement et pays en voie de développement, Informations et Commentaires, $\mathrm{n}^{\circ}$ 68, JuilletSeptembre 1989

Galbraith, J.K. (1984), La paix indésirable? Rapport sur l'utilité des guerres, Calmann Levy. Paris.

Leontiev, W., Duchin, F. (1983), Military spending. Worldwide implications and future outlook, Oxford University Press.

Martin, S., Smith, R.,Fontanel, J. (1987), Time-series estimates of the macroeconomic impact of Defence spending in France and Britain. in Peace, Defence and Economic Analysis, Mac Millan, London, 1987.

Palme, O. and al (1982), Common security, Simon and Schuster, N.Y.

Richardson, L.F. (1960), Arms and insecurity, Benwood.

Royer, J. (1985), Long-term employment impact of disarmament policies, ILO, December.

Schmidt, C., Blackhany, F. (1987) The Economics of Military Expenditures, Mac Millan, London.

Smith, R. P., Humm, A. and Fontanel, J. (1987) Capital-labour substitution in defence provision, Defence, Security and Development, Frances Pinter.

Smith, R., Humm, A., Fontanel, J. (1985), The Economics of Exporting Arms, Journal of Peace Research 2(3).

Thorsson ; I. (1984), In pursuit of disarmament, Report, Stockholm.

UNIDIR (1986), Establishment of an International Disarmament Fund, UNIDIR, Geneva, November. 
UNO (1981), Study on the relationship between disarmament and development, New Yorlk, ONU.

Varas, A. (1983), Military spending and defence in Latin America, Journal of Developing Areas. 18. 